\title{
Efficacy of Entomopathogenic Fungi and Nematodes, and Low Risk Insecticides Against Wheat Stem Sawfly, Cephus cinctus (Hymenoptera: Cephidae)
}

\author{
Khanobporn Tangtrakulwanich ${ }^{1}$, Gadi V. P. Reddy ${ }^{1}$, Shaohui Wu ${ }^{1}$, John H. Miller ${ }^{1}$, Victoria L. Ophus ${ }^{1}$ \\ \& Julie Prewett ${ }^{1}$ \\ ${ }^{1}$ Western Triangle Agricultural Research Center, Montana State University, Conrad, Montana, USA \\ Correspondence: Gadi V. P. Reddy, Western Triangle Agricultural Research Center, Montana State University, \\ Conrad, MT., Montana 59425, USA. Tel: 1-406-278-7707. E-mail: reddy@montana.edu
}

Received: January 21, 2014 Accepted: February 25, 2014 Online Published: April 15, 2014

doi:10.5539/jas.v6n5p1 URL: http://dx.doi.org/10.5539/jas.v6n5p1

\begin{abstract}
Entomopathogenic nematodes, fungi, and low risk insecticides were evaluated for the management of the wheat stem sawfly, Cephus cinctus Norton, in winter wheat at two locations (Devon and Western Triangle Ag Research center) in the Golden Triangle area of Montana (USA) in 2013. Two fungi (Beauveria bassiana and Metarhizium brunneum), four nematodes species (Steinernema carpocapsae, Steinernema kraussei, Steinernema feltiae, and Heterorthabditis bacteriophora), an insect growth regulator (diflubenzuron/dimilin), and a botanical-based chemical (azadirachtin/Aza-direct) were used as foliar sprays. These control agents significantly reduced damage caused by C. cinctus larvae, compared to the untreated control or treatment with water alone. No yield differences were observed among entomopathogenic fungi, nematodes, and low risk insecticides. The effectiveness of azadirachtin, diflubenzuron, the entomopathogenic fungi, and the nematodes persisted at the $28^{\text {th }}$ day post application, by which time the wheat had been harvested. Stubbles collected after harvest showed significantly fewer sawfly larvae in the plots treated with entomopathogenic fungi, nematodes, diflubenzuron, and azadirachtin compared to the untreated and water spray plots, indicating that these biorational pesticides have potential to be used as alternatives to conventional pesticides for controlling the wheat stem sawfly larvae.
\end{abstract}

Keywords: Cephus cinctus, entomopathogenic fungus, nematode, diflubenzuron, azadirachtin

\section{Inroduction}

The wheat stem sawfly, Cephus cinctus Norton (Hymenoptera: Cephidae), is one of the most important pests of wheat, Triticum aestivum L. (Cyperales: Poaceae), especially in the Northern Great Plains of the United States and Canada (Weiss \& Morill, 1992; Morill et al., 1993). Annual losses from this pest exceed $\$ 600$ million (Beres et al., 2011). Sawfly larvae overwinter underground in dead stubbles, and adults emerge in late spring (Ainslie, 1929; Weiss \& Morill, 1992; Gress et al., 2013). Males are haploid with nine chromosomes and typically emerge before females (Holmes, 1979). Mating takes place soon after emergence except for periods of strong wind or rain, which interfere with mating behaviors (Wallace $\&$ McNeal, 1966). Females usually fly near wheat plants and lay one egg per stem per visit, mostly in the upper developing internode (Holmes \& Peterson, 1960). However, there can be multiple eggs deposited in a stem by different females (Buteler et al., 2009). One female can lay 30 to 50 eggs (Wenda-Piesik et al., 2009). The larvae feed on parenchymous and vascular tissues inside wheat stems, causing damage to the wheat by reducing head weight. As the wheat plant matures, the larva moves down to the base of the stem where it cuts a notch at ground level, leading to lodging before harvest, further reducing yield (Beres et al., 2007).

Attempts to control the wheat stem sawfly with conventional pesticides have been either ineffective or cost more than the economic yield return (Knodel et al., 2009). Alternative approaches such as biological control have therefore been considered for the management of this pest. Wenda-Piesik et al. (2009) demonstrated that Fusarium isolates caused mortality in both diapausing wheat stem sawfly larvae in a topical bioassay and developing larvae feeding in infested stems in a greenhouse experiment. Several commercially available fungi and nematodes have been used for biological control of various insect pests. These include Beauveria bassiana (Bals.-Criv.) Vuill (McGuire et al., 2005; Bhadauria et al., 2013), Metarhizium anisopliae (Metschnikoff) Sorokin (Bhat et al., 2010; 
Larramendy et al., 2011), S. carpocapsae Weiser (Cossentine et al., 2002; Chambers et al., 2010), S. kraussei Steiner (Haukeland \& Lola-Luz, 2010), S. feltiae Filipjev (Shapiro-Ilan et al., 2004; Navaneethan et al., 2010), and Heterorhabditis bacteriophora Poinar (Toledo et al., 2005; Koppenhöfer et al., 2006). Dimilin is an insect growth regulator which has been reported to be effective in mosquito control (Msangi et al., 2011). Neem (Aza-direct) has also been reported to be effective against some insects (Mamoon-ur-Rashid et al., 2013, Sivasakthi et al., 2013). This study was aimed to investigate the potential use of these biorational control agents for the management of $C$. cinctus.

\section{Materials and Methods}

\subsection{Trial Design and Location}

Two trials were conducted, one at the Montana State University Western Triangle Agricultural Research Center (WTARC) (N48 $\left.18^{\prime} 24.88^{\prime \prime} \mathrm{W} 111^{\circ} 55^{\prime} 28.45^{\prime \prime}\right)$ and the other at Devon, Montana (N48 $\left.33^{\prime} 14.94^{\prime \prime} \mathrm{W} 111^{\circ} 23^{\prime} 42.96^{\prime \prime}\right)$. The distance between the two locations was 58 miles. The experiments were carried out from May-September 2013. Winter wheat Yellowstone variety was used for these trials. The wheat was seeded at the rate of 194 live seeds per $\mathrm{m}^{2}$. In both trials, the wheat was planted in four rows, with $30 \mathrm{~cm}$ between rows. Glyphosate (Roundup Powermax) was applied at the rate of $2.5 \mathrm{~L} /$ ha (active ingredient of $540 \mathrm{~g} / \mathrm{L}$ of acid glyphosate) before the wheat was seeded to control weed growth. Fertilizer N, P, and K ratio at 224.2, 0, and $22.4 \mathrm{~kg} / \mathrm{ha}$ was broadcasted while planting, and an additional application of $12.3,25.2$, and $0 \mathrm{~kg} / \mathrm{ha}$ of these three nutrients were placed through seed plot drill. The treatment plots were arranged in a complete randomized design (CRD) with four replicates.

Treatment plots were $8 \mathrm{~m} \times 4 \mathrm{~m}$ and there was $2 \mathrm{~m}$-distance between adjacent treatment plots to avoid spray drift. Each plot consisted of four rows. Standing plants were counted after seed germination. There were approximately 142 standing plants per $\mathrm{m}^{2}$ in each plot. In each plot, control agents (Table 1) were sprayed after stem elongation had begun. The spray of each treatment was conducted only once at this plant stage. Treatment materials were mixed in a Chapin Lawn \& Garden Sprayer, and sprayed at 297 L water per hectare, pressure ranges 241 to 310 Kpa.

Table 1. Materials and rates applied in each treatment

\begin{tabular}{|c|c|c|c|}
\hline Treatment & Active Ingredient & Dose & Source \\
\hline T1: Control (no spray) & No treatment & - & - \\
\hline T2: Water spray & - & - & - \\
\hline T3: Mycotrol ${ }^{\circledR}$ & $\begin{array}{l}\text { Beauveria bassiana Strain GHA } \\
\left(2.11 \times 10^{10} \text { viable spores } / \mathrm{ml}\right)\end{array}$ & $712 \mathrm{ml} / \mathrm{ha}$ & $\begin{array}{l}\text { Laverlam International } \\
\text { Corporation, Butte, MT }\end{array}$ \\
\hline T4: Met 52G & $\begin{array}{l}\text { Metarhizium brunneum Strain F52 } \\
\left(5 \times 10^{9} \text { viable conidia/g) }\right.\end{array}$ & $1484 \mathrm{~g} / \mathrm{ha}$ & Novozymes, Davis, CA \\
\hline T5: Millenium ${ }^{\circledR}$ & Steinernema carpocapsae & $\begin{array}{l}2.3 \times 10^{7} \text { infective } \\
\text { juveniles }(\mathrm{IJs}) / \mathrm{ha}\end{array}$ & $\begin{array}{l}\text { Becker Underwood } \\
\text { Ames, Iowa }\end{array}$ \\
\hline T6: Nemasys ${ }^{\circledR}$ L & Steinernema kraussei & $2.3 \times 10^{7} \mathrm{IJs} / \mathrm{ha}$ & $\begin{array}{l}\text { Becker Underwood } \\
\text { Ames, Iowa }\end{array}$ \\
\hline T7: Nemasys ${ }^{\circledR}$ & Steinernema feltiae & $2.3 \times 10^{7} \mathrm{IJs} / \mathrm{ha}$ & $\begin{array}{l}\text { Becker Underwood } \\
\text { Ames, Iowa }\end{array}$ \\
\hline T8: Nemasys ${ }^{\circledR} \mathrm{G}$ & Heterorhabditis bacteriophora & $2.3 \times 10^{7} \mathrm{IJs} / \mathrm{ha}$ & $\begin{array}{l}\text { Becker Underwood } \\
\text { Ames, Iowa }\end{array}$ \\
\hline $\begin{array}{l}\text { T9: Growth Hormone } \\
\text { (Dimilin) }\end{array}$ & $\begin{array}{l}\text { Benzoylurea-type insecticide of } \\
\text { benzamide class }\end{array}$ & $148 \mathrm{~g} / \mathrm{ha}$ & $\begin{array}{l}\text { Chemtura company, } \\
\text { Middlebury, CT }\end{array}$ \\
\hline T10: Neem (Aza-direct) & Azadirachtin $1.2 \%$ & $1484 \mathrm{ml} / \mathrm{ha}$ & $\begin{array}{l}\text { Gowan Company, } \\
\text { Yuma, AZ }\end{array}$ \\
\hline
\end{tabular}

Stem damage was assessed weekly after treatment. Treatments were applied on 07/25/2013 and data were collected on $08 / 01 / 2013,08 / 06 / 2013,08 / 12 / 2013$, and $08 / 19 / 2013$, respectively, by counting the number of stems lodged in randomly selected $1 \mathrm{~m}^{2}$ area. A $1 \mathrm{~m}^{2}$ quadrat was randomly thrown into each plot to choose the area to 
assess the stem damage (Reddy, 2011). The wheat was harvested in late August in 2013. A Hedge 140 plot combine was used to thresh the wheat plots and the grain yield was recorded as grain weight produced in each plot divided by the plot area. To measure pest density after harvest, ten pieces of wheat stubbles were randomly uprooted from each plot at $1^{\text {st }}, 2^{\text {nd }}, 3^{\text {rd }}$ and $4^{\text {th }}$ week after harvest $(08 / 28 / 2013,09 / 5 / 13,09 / 12 / 13,09 / 23 / 13)$ and the number of $C$. cinctus larvae inside stems was recorded.

\subsection{Statistical Analyses}

Analyses of variance (ANOVA) was used to analyze differences among treatments in yield, number of stems damaged, and number of sawfly larvae per stubble. The locations were treated as random effect (Random, 2 levels) and the treatments were treated as fixed effect (Fixed, 10 levels). Homogeneity of variances among treatments was tested by using Bartlett's test and no transformed data was conducted. Means were compared using least square difference (LSD) test. Values of $P<0.05$ were considered significant. All analyses were conducted using SAS version 9.3 (SAS Institute 2011).

\section{Results}

\subsection{Stem Damage}
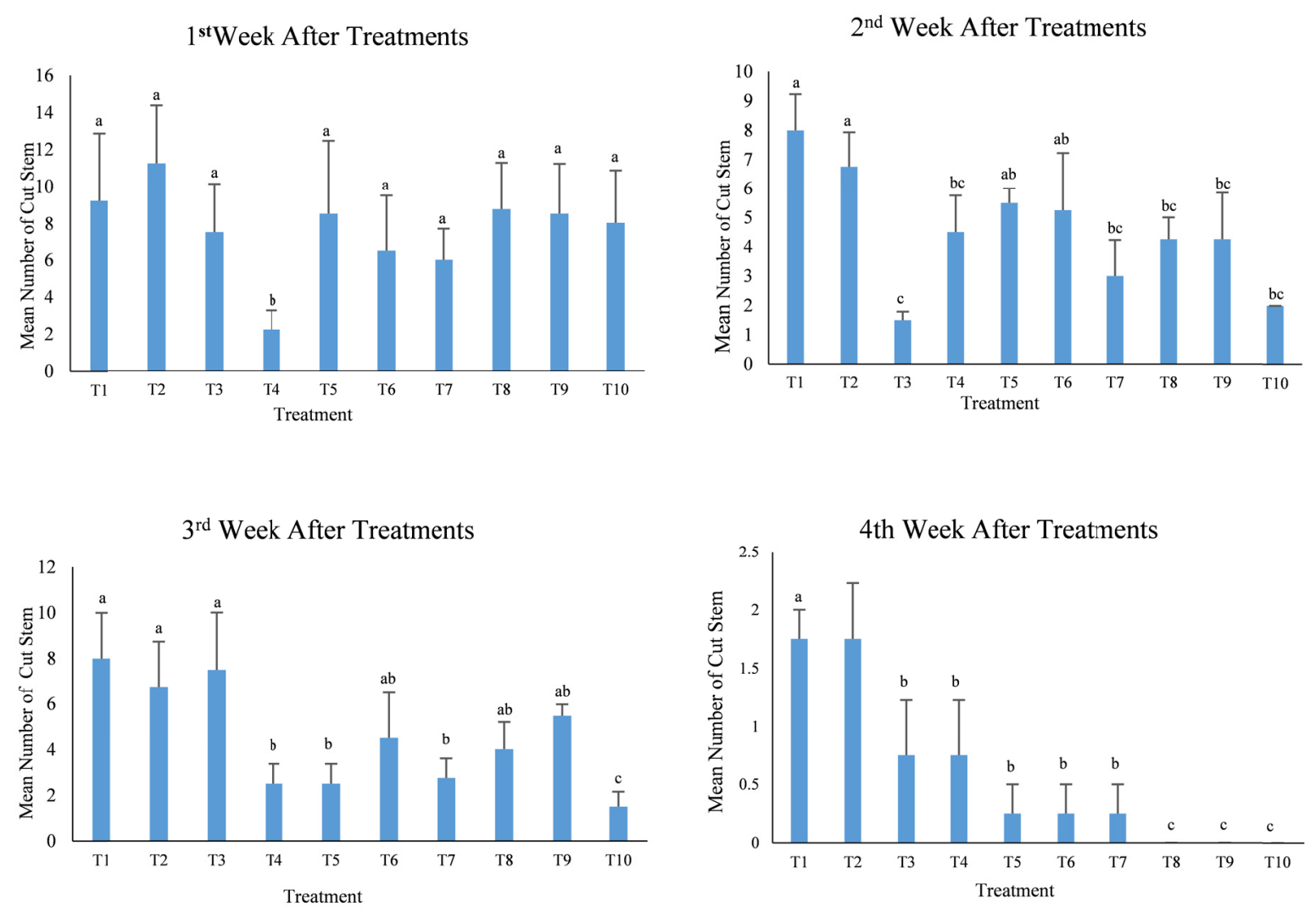

Figure 1. Number of cut stem in plots treated with control materials for Cephus cinctus (mean $\pm \mathrm{SEM}$ ). Different letters indicate significant differences (Two-way ANOVA, LSD test, $\alpha=0.05$ ). $\mathrm{T} 1=$ control (no treatment); $\mathrm{T} 2=$ control (water spray); T3 = Beauveria bassiana; $\mathrm{T} 4=$ Metarhizium brunneum; $\mathrm{T} 5=$ Steinernema carpocapsae; T6

$=$ Steinernema krausse $; \mathrm{T} 7=$ Steinermema feltiae $; \mathrm{T} 8=$ Heterorhabditis bacteriophora $; \mathrm{T} 9=$ Dimilin; $\mathrm{T} 10=$ Neem (Aza-direct). Data were recorded on 08/01/2013, 08/06/2013, 08/12/2013, and 08/19/2013

In the first week after treatment, there were no significant differences among the untreated control, water spray, $B$. bassiana, S. carpocapsae, S. kraussei. S. feltiae, H. bacteriophora, Dimilin, and Aza-direct $\left(\mathrm{F}_{8,63}=0.50, P>0.05\right.$; Figure 1). Plots treated with $M$. brunneum had significantly lower stem damage compared to other treatments $\left(\mathrm{F}_{9,70}=2.24, P<0.05\right)$. In the second week, we found no significant differences among the untreated, B. bassiana, S. carpocapsae, and $S$. kraussei treated plots $\left(\mathrm{F}_{3,28}=0.77, P>0.05\right)$. There were no significant differences among plots treated with M. brunneum, S. carpocapsae, S. kraussei, S. feltiae, H. bacteriophora, Dimilin, and Aza-direct $\left(\mathrm{F}_{6,49}=0.61, P>0.05\right)$. The plots treated with $B$. bassiana had significant lower stem damage compared to other 
treatments except for plots treated with $S$. feltiae and Aza-direct $\left(\mathrm{F}_{9,70}=2.24, P<0.05\right)$. Stem damage in the third week was not significantly different among the untreated control, water spray, and treatments with $B$. bassiana, $S$. kraussei, H. bacteriophora, or Dimilin $\left(\mathrm{F}_{5,42}=0.59, P>0.05\right)$. No significant differences were found among treatments with $M$. brunneum, $S$. carpocapsae, or $S$. feltiae $\left(\mathrm{F}_{2,21}=0.12, P>0.05\right)$. These three treatments differed significantly to the untreated control, water spray, and B. bassiana $\left(\mathrm{F}_{5,42}=2.35, P<0.05\right)$, but did not differ significantly from treatments with $S$. kraussei, $H$. bacteriophora, and Dimilin $\left(\mathrm{F}_{5,42}=0.24, P>0.05\right)$. Plots treated with $B$. bassiana had significant lower stem damage compared to other treatments in the third week after spray $\left(\mathrm{F}_{9,70}=2.34, P<0.05\right)$. In the fourth week, there were no significant differences between the untreated and water sprayed plots $\left(\mathrm{F}_{1,14}=0.58, P>0.05\right)$. Both the untreated control and water spray treatment had significant higher stem damage than treatments with B. bassiana, M. brunneum, S. carpocapsae, S. kraussei, and S. feltiae $\left(\mathrm{F}_{6,49}=3.46, P<0.05\right)$. No significant differences were found among water spray, B. bassiana, M. brunneum, $S$. carpocapsae, $S$. kraussei, and $S$. feltiae $\left(\mathrm{F}_{5,42}=1.15, P>0.05\right)$. No stem damage was found in treatments with $H$. bacteriophora, Dimilin and Aza-direct (Figure 1).

\subsection{Number of larvae}
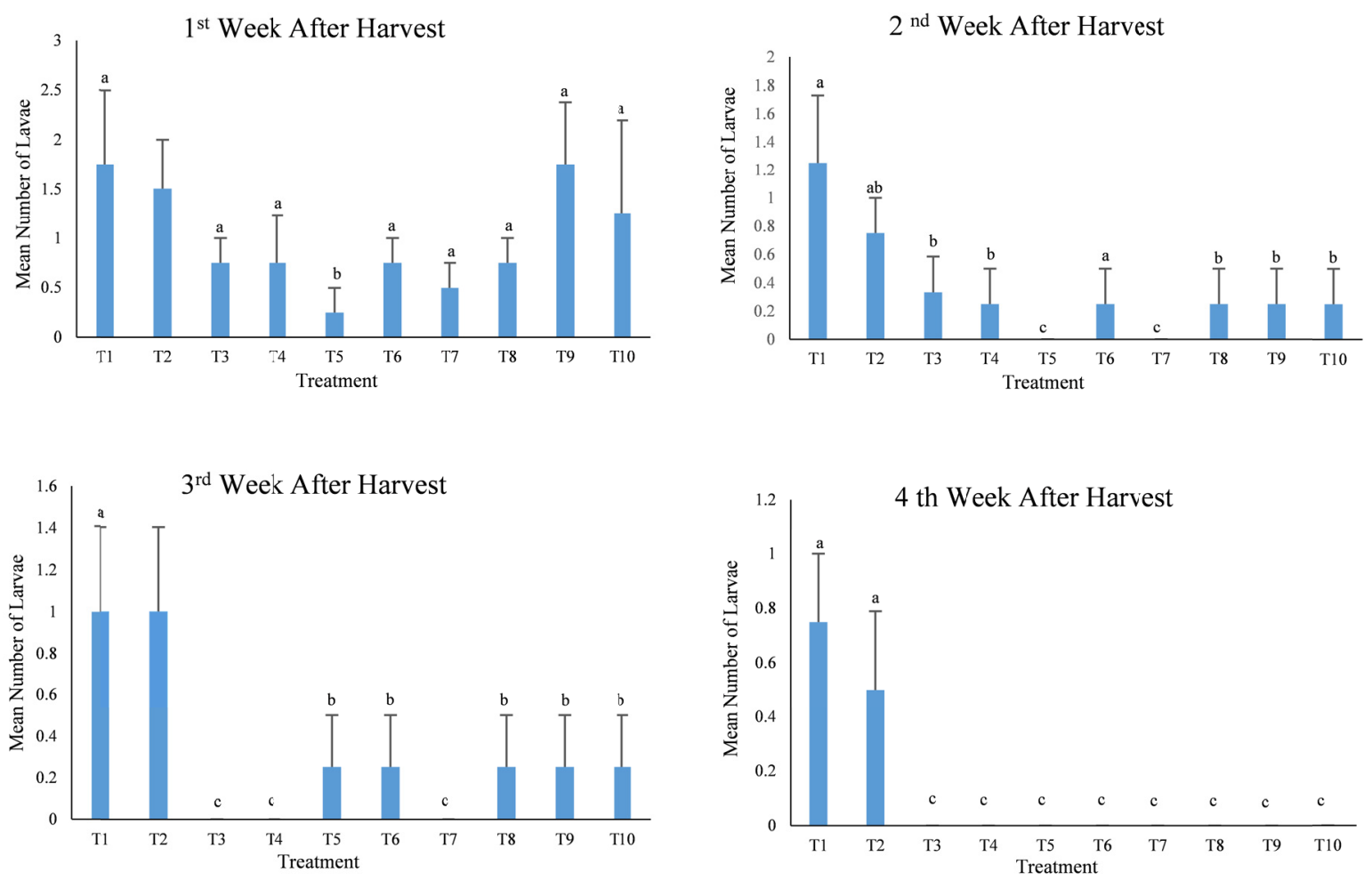

Figure 2. Number of Cephus cinctus larvae per stem at different times after treatment with different agents (mean \pm SEM). Different letters indicate significant differences (Two-way ANOVA, LSD test, $\alpha=0.05$ ). T1 = control

(no treatment); T2 = control (water spray); T3 = Beauveria bassiana; T4= Metarhizium brunneum; T5=

Steinernema carpocapsae; T6 = Steinernema kraussei; T7 = Steinermema feltiae; T8 = Heterorhabditis bacteriophora; T9 = Dimilin; T10 = Neem (Aza-direct) Data were recorded on 08/28/2013, 09/5/13, 09/12/13, $09 / 23 / 13$

In the first week after treatment, all other treatments had significantly more larvae than plots treated with $S$. carpocapsae ( $\mathrm{F}_{9,70}=2.05, P<0.05$ ) (Figure 2). No significant differences were found among the untreated control, water spray, B. bassiana, M. brunneum, S. kraussei, S. feltiae, H. bacteriophora, Dimilin, and Aza-direct $\left(\mathrm{F}_{8,63}=1.11, P>0.05\right)$. In the second week, the untreated plots showed significantly higher number of larvae than other treatments, except for water sprayed plots $\left(\mathrm{F}_{9,70}=3.04, P<0.05\right)$. There was no significant difference between the untreated control and water spray $\left(\mathrm{F}_{1,14}=0.77, P>0.05\right)$. Plots treated with B. bassiana, M. brunneum, S. kraussei, H. bacteriophora, Dimilin, and Aza-direct did not differ significantly in number of larvae $\left(\mathrm{F}_{5,42}=1.68\right.$, $P>0.05)$. Plots treated with $S$. carpocapsae and $S$. feltiae had significantly fewer larvae than other treatments $\left(F_{9}\right.$, 
$70=2.45, P<0.05$ ) (Figure 2). In the third week, the untreated and water sprayed plots had significantly more larvae than other treatments $\left(\mathrm{F}_{9,70}=2.34, P<0.05\right)$. There were no significant differences in the number of larvae found among treatments with $S$. carpocapsae, $S$. kraussei, H. bacteriophora, Dimilin and Aza-direct $\left(\mathrm{F}_{4,35}=0.94\right.$, $P>0.05$ ). Plots treated with $B$. bassiana, M. brunneum, and $S$. feltiae had significantly fewer larvae than other treatments $\left(\mathrm{F}_{9,70}=2.23, P<0.05\right)$. In the fourth week, only the untreated and water sprayed plots had significantly more larvae than other treatments $\left(\mathrm{F}_{9,70}=4.39, P<0.05\right)$; the water spray treatment did not have a significantly different effect from the untreated control $\left(\mathrm{F}_{1,14}=0.00, P>0.05\right)$. No larvae were found in plots treated with $B$. bassiana, M. brunneum, S. carpocapsae, S. kraussei, S. feltiae, H. bacteriophora, Dimilin and Aza-direct.

\subsection{Effect on Yield}

There were no significant differences in wheat yield between the control plots and plots treated with water $\left(\mathrm{F}_{1,14}\right.$ $=0.15, P>0.05$ ). There were no significant difference in yield among plots treated with B. bassiana, M. brunneum, S. carpocapsae, S. kraussei, S. feltiae, H. bacteriophora, Dimilin, and Aza-direct. However, plots treated with these agents produced significantly higher yield than either the untreated control or the water spray $\left(\mathrm{F}_{9,70}=2.27, P<0.05\right)$ (Figure 3).

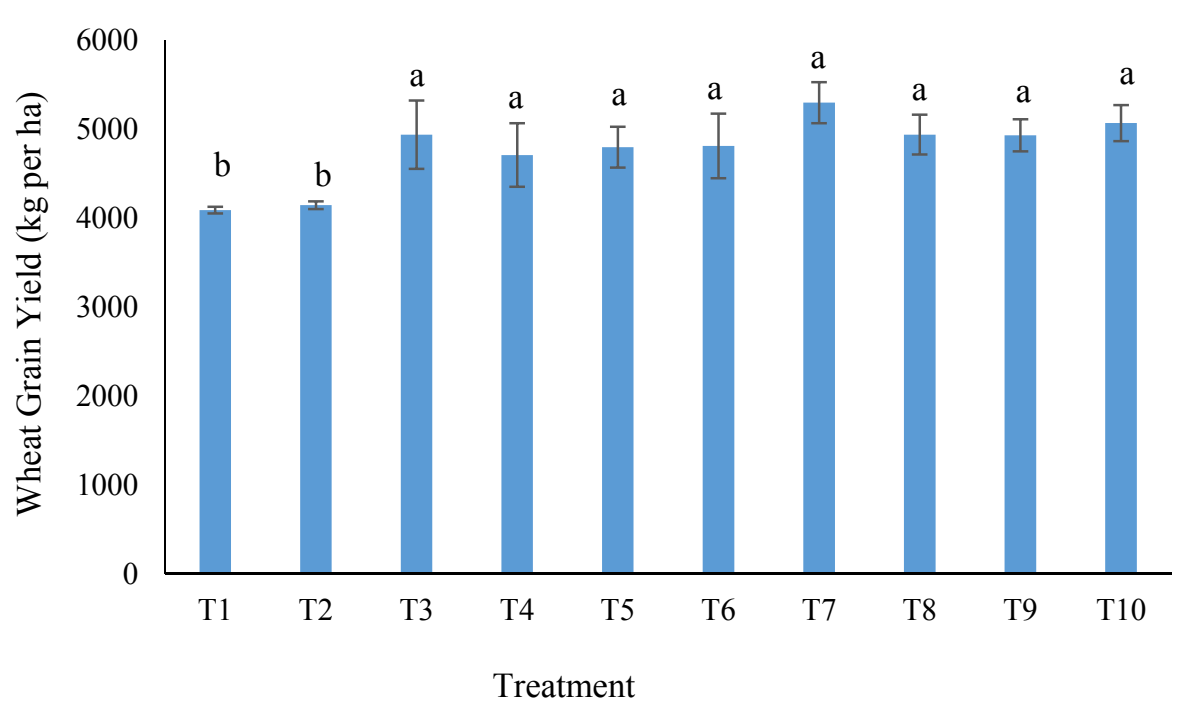

Figure 3. Wheat yield production in treatments with different agents (mean $\pm \mathrm{SEM})$. Different letters indicate significant differences (Two-way ANOVA, LSD test, $\alpha=0.05$ ). T1 $=$ control (no treatment); $\mathrm{T} 2=$ control (water spray); T3 = Beauveria bassiana $; \mathrm{T} 4=$ Metarhizium brunneum; $\mathrm{T} 5=$ Steinernema carpocapsae $; \mathrm{T} 6=$ Steinernema krausse $; \mathrm{T} 7=$ Steinermema feltiae $; \mathrm{T} 8=$ Heterorhabditis bacteriophora $; \mathrm{T} 9=$ Dimilin; $\mathrm{T} 10=$ Neem (Aza-direct)

\section{Discussion}

Currently, the management of $C$. cinctus is often limited to the use of solid-stemmed resistant cultivars. Chemical pesticides are either ineffective or more costly than the economic yield return (Knodel et al., 2009). The development of biological control agents against this pest is an important alternative approach for the management of $C$. cinctus. In the current study, treatments with the entomopathogenic fungi and nematodes resulted in higher yield production and better control of $C$. cinctus compared to the untreated control and water spray.

Results of our study showed that the fungi B. bassiana (Mycotrol) and M. brunneum (Met 52) effectively reduced wheat stem damage caused by $C$. cinctus larvae compared to the untreated plots or water spray only (Figure 1). Beauveria bassiana has been found to control many insects (Bhadauria et al., 2013). Also, M. brunneum has been documented to infect more than 200 pest species (Robert \& Leger, 2004). However, to our knowledge, no work has been done to evaluate the effectiveness of these entomopathogenic fungi against $C$. cinctus. Both $B$. bassiana and $M$. brunneum kill insects via infection following spore contact with spray droplets or treated surfaces, or by consuming plant tissue treated with the fungus. After contact, spores germinate and hyphae infect the insect (EPA, 2011). Infected insects die in 3-5 days, and the cadavers may serve as source of spores for secondary spread of the fungal entomopathogen. In addition, adult insects may spread the fungus through mating (Long et al., 2000). 
In our study, we found that the effectiveness of the two fungal entomopathogens started to take effect 21 to 28 days after application, in terms of reducing number of cut stems, which occurred at the third week for M. brunneum (Met52) and the fourth week for B. bassiana (Mycotrol) (Figure 2). Being consistent with stem cuts, the plots treated with the two fungi showed significantly lower number of $C$. cinctus larvae by the third and fourth weeks after wheat harvest (Figure 2).

Entomopathogenic nematodes have many attributes of effective biological control agents (Kaya \& Gaugler, 1993; Grewal et al., 2005; Koppenhöfer, 2007). In our current study, S. carpocapsae (Millenium ${ }^{\circledR}$ ), S. kraussei (Nemasys ${ }^{\circledR}$ L), S. feltiae $\left(\right.$ Nemasys $\left.^{\circledR}\right)$, and H. bacteriophora $\left(\right.$ Nemasys ${ }^{\circledR} \mathrm{G}$ ) appeared to be effective in reducing the damage caused by $C$. cinctus larvae and increased the yields compared to the untreated control and treatment with water spray alone (Figure 3). Georgis et al. (1991) also reported that Steinernematid and Heterorhabditid nematodes significantly suppressed pest populations such as Popilla japonica Newman (Coleoptera: Scarabaeidae), Scapteriscus vicinus Scudder (Orthoptera: Gryllotalpidae), Otiorhynchus sulcatus Fabricius (Coleoptera: Curculiondae), Delia radicum Linnaaeus (Diptera: Anthomylidae), and Diabrotica virgifera viergifera LeConte (Coleoptera: Chrysomelidae) in the field. These entomopathogenic nematodes were also proven to have no adverse effect to nontarget arthropods especially when used for short-term control of insect pests (Georgis et al., 1991). All entomopathogenic nematodes used in our experiment were equally effective in reducing the stem damage within three weeks after spray (Figure 1). However, by 28 days after application, $H$. bacteriophora (Nemasys ${ }^{\circledR} \mathrm{G}$ ) showed significantly higher efficacy in reducing stem cut damage compared to other nematode species (Figure 1). Different from our study, Kamali et al. (2013) reported that S. carpocapsae had higher virulence and better ability to locate larvae of Dacus ciliatus Loew (Diptera: Tephritidae) within infected fruits. Temperature thresholds for survival and infectivity vary with nematode species, their native habitat, and center of origin (Kaya, 1990). The average temperatures in the first 2 and 3 weeks after treatment were $29.3^{\circ} \mathrm{C}$ and $21.7^{\circ} \mathrm{C}$, respectively. The optimal temperature for $S$. feltiae to be infective ranges from 20 to $30^{\circ} \mathrm{C}$, whereas some heterorhabiditids can infect host from 7 to $35^{\circ} \mathrm{C}$, and $S$. carpocapsae fails to cause infection when temperature drops below $10^{\circ} \mathrm{C}$ (Kaya, 1990; Georgis et al., 2006; Lacey et al., 2006). However, this may also vary with host species. Different host insects might have different cues and characteristics under different temperatures which means the temperature can affect host recognition by nematodes and also the host itself can produce less cues depending on temperatures (Chen et al., 2003). By the fourth week after harvest, we found no sawfly larvae in wheat stubbles in any nematode treatment, indicating that these nematodes effectively controlled the insect within 28 days after harvest.

Our study also showed that Dimilin was effective in controlling the damage caused by $C$. cinctus larvae compared to the treatment with water spray only and the untreated control (Figures. 1, $2 \& 3$ ). Diflubenzuron (Dimilin) kills insects by interfering with chitin synthesis and disrupting insect growth. Dimilin has been shown to be effective in controlling larvae of Anopheles gambiae Giles (Diptera: Culcidae) (Msangi et al., 2011), Culex quinquefasciatus Say (Diptera: Culcidae) (Msangi et al., 2011), Musca domestica Linnaeus (Diptera: Muscidae) (Batra et al., 2005; Le Menach et al., 2007; WHO, 1984).

In addition, treatment with neem extracts showed significantly lower stem damage and fewer $C$. cinctus larvae compared to the untreated control and treatment with water spray alone (Figures 1,2). Neem extracts are reported to affect over six hundred species of pests (Sivasakthi et al., 2013). Reddy and Guerrero (2000) suggested that neem had the potential to be used as a good alternative to conventional insecticides in IPM programs. In the current study, neem effectively suppressed C. cinctus populations (Figure 2).

Overall, all bio-rational agents used in the current study demonstrated good potential for controlling the $C$. cinctus. Among them, B. bassiana (Mycotrol), M. brunneum (Met 52), and S. feltiae (Numasys) were effective in killing the larvae within a shorter period of time compared to other agents. Our study indicated that these biopesticides may serve as alternative methods for controlling $C$. cinctus and may be incorporated into IPM programs, to mitigate the environmental pressure from the use of conventional insecticides.

\section{Acknowledgements}

This work was supported by United States Department of Agriculture- Cooperative Regional Project W3185 Biological Control in Pest Management Systems of Plants and Montana Wheat and Barley Committee. We greatly appreciated Mr. Brian Aklestad for allowing us to use his wheat field to conduct the experiment in Devon, Montana.

\section{References}

Ainslie, C. N. (1929) .The western grass-stem sawfly: A pest of small grains. United States Department of Agricultural Technology Bulletin, 57, 1-24. 
Batra, C. P., Mittal, P. K., Adak, T., \& Ansari, M. A. (2005). Efficacy of IGR compound starycid 480 SC (Triflumuron) against mosquito larvae in clear and polluted water. Journal of Vector Borne Diseases, 42, 109-116.

Beres, B. L., Cárcamo, H. A., \& Byers, J. R. (2007). Effect of wheat stem sawfly damage on yield and quality of selected Canadian spring wheat. Journal of Economic Entomology, 100, 79-87. http://dx.doi.org/10.1603/0022-0493 (2007)100[79: EOWSSD] 2.0.CO; 2

Beres, B. L., Dosdall, L. M., Weaver, D. K., Cárcamo, H. A., \& Spaner, D. M. (2011). Biology and integrated management of wheat stem sawfly and the need for continuing research. Canadian Entomologist, 143, 105-125. http://dx.doi.org/10.4039/n10-056

Bhadauria, B. P., Singh, P. K., Pandey, S., Zaidi, N. W., \& Singh, U. S. (2013). Characterization and biocontrol potential of entomopathogenic fungus, Beauveria bassiana isolates against Spilarctia oblique. Journal of Environmental Biology, 34, 917-921.

Bhat, J. A., Wani, N. A., Mohi-ud-din, S., Lone, G. M., \& Pukhta, M. S. (2010). Relatives virulence of local entomopathogenic fungai isolates infecting apple stem borer. Aeolesthes sarta, Solsky, 18, 153-155.

Buteler, M., Weaver, D. K., \& Peterson, R. K. D. (2009). Oviposition behavior of the wheat stem sawfly when encountering plants infested with cryptic conspecifics. Environmental Entomology, 38, 1707-1715. http://dx.doi.org/10.1603/022.038.0624

Chambers, U., Bruck, D. J., Olsen, J., \& Walton, V. M. (2010). Control of overwintering fibertworm (Lepidoptera: Torticidae) larvae with Stenernema carpocapsae. Journal of Economic Entomology, 103, 416-422. http://dx.doi.org/10.1603/EC09255

Chen, S., Li, J., Han, X., \& Moens, M. (2003). Effect of temperature on the pathogenicity of entomopathogenic nematodes (Steinernema and Heterorhabditis spp.) to Delia radicum. Biological Control, 48, 713-724.

Cossentine, J. E., Jensen, L. B., \& Moyls, L. (2002). Fruit bins washed with Stenernema carpocapsae (Rhabditida: Steinernematidae) to control Cydia pomonella (Lepidoptera: Tortircidae). Bioloical Control, 12, 251-258.

EPA (Environmental Protection Agency). (2011). Biopesticide registration. Retrieved January 4, 2014, from http://www.epa.gov/opp00001/chem_search/reg_actions/registration/

Georgis, R., Kaya, H. K., \& Gaugler, R. (1991). Effect of Steinernematid and Heterorhabditid nematodes (Rhabditida: Steinernematidae and Heterorhabditidae) on nontarget arthropods. Environmental Entomology, 20, 815-822.

Georgis, R., Koppenhöfer, A. M., Lacey, L. A., Bélair, G., Duncan, L. W., Grewal, P. S., ... van Tol, R. W. H. M. (2006). Success and failures in the use of parasitic nematodes for pest control. Biological Control, 38, 103-123. http://dx.doi.org/10.1016/j.biocontrol.2005.11.005

Gress, J. C., Robertson, H. M., Weaver, D. K., Dlakić, M., \& Wanner, K. W. (2013). Odorant receptors of a primitive hymenopteran pest, the wheat stem sawfly. Insect Molecular Biology, 26, 659-667. http://dx.doi.org/10.1111/imb.12053

Grewal, P. S., Ehlers, R. U., \& Shapiro-Ilan, D. I. (2005). Nematodes as biological agents. Wallingford, UK: CABI. http://dx.doi.org/10.1079/9780851990170.0000

Haukeland, S., \& Lola-Luz, T. (2010). Efficacy of the entomopathogenic nematodes Steinernema kraussei and Heterorhabditis megidis against the black vine weevil Otiorhynchus sulcatus in open field grown strawberry plants. Agricultural Forest Entomology, 12, 363-369. http://dx.doi.org/10.1111/j.1461-9563.2010.00497.x

Holmes, N. D. (1979). The wheat stem sawfly. In Proceedings, $26^{\text {th }}$ Annual Meeting of the Entomological Society of Alberta (pp. 2-13), 19-21 October 1978, Agriculture Center Lethbridge, Alberta.

Holmes, N. D., \& Peterson, L. K. (1960). The influence of the host on oviposition by the wheat stem sawfly, Cephus cinctus Nort. (Hymenoptera: Cephidae). Canadian Journal of Plant Science, 40, 29-40. http://dx.doi.org/10.4141/cjps60-004

Kamali, S., Karimi, J., Hosseini, M., Campos-Herrera, R., \& Duncan, L. W. (2013). Biocontrol potential of the entomopathogenic nematodes Heterorthabditis bacteriophora and Steinernema carpocapsae on cucurbit fly, Dacus cilatus (Diptera: Tephritidae). Biocontrol Science and Technology, 23, 1307-1323. http://dx.doi.org/10.1080/09583157.2013.835790 
Kaya, H. K. (1990). Soil ecology. In R. Gaugler, \& H. K. Kaya (Eds.), Entomopathogenic nematodes in biological control (pp. 93-115). Boca Ration, Florida: CRC Press.

Kaya, H. K., \& Gaugler, R. G. (1993). Entomopathogenic nematodes. Annual Review of Entomology, 38, 181-206. http://dx.doi.org/10.1146/annurev.ento.38.1.181

Knodel, J. J., Beuzay, P. B., Eriksmoen, E. D., \& Pederson, J. D. (2009). Pest management of wheat stem maggot (Diptera: Chloropidae) and wheat stem sawfly (Hymenoptera: Cephidae) using insecticides in spring wheat. Journal of Agricultural and Urban Entomology, 26, 183-197. http://dx.doi.org/10.3954/1523-5475-26.4.183

Koppenhöfer, A. M. (2007). Nematodes. In L. A. Lacey, \& H. K. Kaya (Eds.), Field manual of techniques in invertebrate pathology: Application and evaluation of pathogens for control insects and other invertebrate pests (2nd ed., pp. 246-264). Dordrecht, NL: Springer. http://dx.doi.org/10.1007/978-1-4020-5933-9_11

Koppenhöfer, A. M., Grewal, P. S., \& Fuzy, E. M. (2006). Virulence of the entomopathogenic nematodes Heterorhabditis bacteriophora, Heterorhabditis zealandica, and Steinernema scarabaei agaist five white grub species (Coleoptera: Scarabaeidae) of economic importance in turfgrass in North America. Biological Control, 38, 397-404. http://dx.doi.org/10.1016/j.biocontrol.2005.12.013

Lacey, L. A., Arthurs, S. P., Unruh, T. R., Headrick, H., \& Fritts, R. Jr. (2006). Entomopathogenic nematodes for control of coding moth (Lepidoptera: Tortricidae) in apple and pear orchards: effect of nematode species and seasonal temperatures, adjuvants, application equipment and post-application irrigation. Biological Control, 37, 214-223. http://dx.doi.org/10.1016/j.biocontrol.2005.09.015

Larramendy, R., Szczypel, B., Morales, Y., Temprana, M., \& Carla, R. (2011). Evaluation of different concentrations of the mushroom entomopathogenic Metarhizium anisopliae in front of coleopterons (Alphitobius diaperinus and Demestes ater) helminthes innkeeper in hen. Revista Cubana de Ciencia Avicola, 35, 33-38.

Le Menach, A., Takala, S., Mckenzie, F. E., Perisse, A., Harris, A., Flahault, A., \& Smith, D. L. (2007). An elaborated feeding cycle model for reductions in vectorial capacity of night-biting mosquitoes by insecticide-treated nets. Malaria Journal, 6, 1-10. http://dx.doi.org/10.1186/1475-2875-6-10

Long, D. W., Drummond, G. A., \& Groden, E. (2000). Horizontal transmission of Beauveria bassiana. Agricultural Forest Entomology, 2, 11-17. http://dx.doi.org/10.1046/j.146-9563.2000.00046.x

Mamoon-ur-Rashid, M., Khattak, M. K., Abdullah, K., Hashim, M. M., Amir, M., \& Khan, M. P. (2013). Effect of neem derivatives on spotted bollworm Earias sp. (Lepidoptera: Noctuidae) and its egg parasitoid, Trichogramma chilonis (Ishi) (Hymenoptera: Trichogrammatidae). African Entomology, 21, 304-309. http://dx.doi.org/10.4001/003.021.0211

McGuire, M. R., Ulloa, M., Park, Y. H., \& Hudson, N. (2005). Biological and molecular characteristics of Beauveria bassiana isolates from California Lygus hesperus (Hemiptera: Miridae) populations. Biological Control, 33, 307-314. http://dx.doi.org/10.1016/j.biocontrol.2005.03.009

Morill, W. L., Gabor, J. W., \& Wichman, D. (1993). Mortality of the wheat stem sawfly (Hymenoptgera: Cephidae) at low temperatures. Enviromental Entomology, 22, 1358-1361.

Msangi, S., Lyatuu, E., \& Kweka, J. E. (2011). Field and laboratory evaluation of bioefficacy of an insect growth regulator (dimilin) as a larvicide against mosquito and housefly larvae. Journal of Tropical Medicine, 2011.

Navaneethan, T., Strauch, O., Besse, S., Bonhomme, A., \& Ehlers, R. (2010). Influence of humidity and a surfactant-polymer formulation on the control potential of the entomopathogenic nematode Steinernema feltiae against diapausing codling moth larvae (Cydia pomonella L.) (Lepidoptera: Tortricidae). Biocontrol, 55, 777-788. http://dx.doi.org/10.1007/s10526-010-9299-5

Reddy, G. V. P. (2011). Survey of invasive plants on Gaum and identification of the 20 most widespread. Micronesia, 41, 263-274.

Reddy, G. V. P., \& Guerrero, A. (2000). Pheromone-based integrated pest management to control the diamondback moth, Plutella xylostella in cabbage fields. Pest Management Science, 56, 882-888. http://dx.doi.org/10.1002/1526-4998(200010)56:10<882:AID-PS226>3.0.CO;2-T

Roberts, D. W., \& Legger, R. J. St. (2004). Metarhizium spp., cosmopolitan insect pathogenic fungi: Mycological aspects. Advance Apply Microbiology, 54, 1-70. http://dx.doi.org/10.1016/S0065-2164(04)54001-7 
Shapiro-Ilan, D. I., Mizell, R. F., Cottrell, T. E., \& Horton, D. L. (2004). Measuring field efficacy of Steinernema feltiae and Steinerma riobrave for suppression of plum curculio, Conotrachelus nenuphar larvae. Biological Control, 30, 496-503. http://dx.doi.org/10.1016/j.biocontrol.2003.12.006

Sivasakthi, M. V., Dhanasekaran, S., \& Manimegalai, K. (2013). Impact of neem oil on the feeding physiology and protein estimation of polyphagous pest (Pericalliaricini) (Lepidoptera: Arctidae). International Journal of Pharma and Bio Sciences, 4, B259- B263.

Toledo, J., Ibarra, J. E., Liedo, P., Gomez, A., Rasgado, M. A., \& Williams, T. (2005). Infection of Anastrepha ludens (Diptera: Tephiritidae) larvae by Heterorhabditis bacteriophora conditions. Biocontrol Science Technology, 15, 627-634. http://dx.doi.org/10.1080/09583150500089049

Wallace, L. E., \& McNeal, F. H. (1966). Stem sawflies of economic importance in grain crops in the United States. Washington, DC: U.S. Government Printing Office.

Weiss, M. J., \& Morill, W. L. (1992). Wheat stem sawfly (Hymenoptera: Cephidae) revisited. American Entomology, 38, 241-245.

Wenda-Piesik, A., Sun, Z. T., Greg, W. E., Weaver, D. K., \& Morill, W. L. (2009). Mycoses of wheat stem sawfly (Hymenoptera: Cephidae) larvae by Fusarium spp. isolates. Environmental Entomology, 38, 387-394. http://dx.doi.org/10.1603/022.038.0211

WHO. (1984). Chemical methods for the control of arthropod vectors and pests of public health importance. Geneva, Switzerland: World Health Organization.

\section{Copyrights}

Copyright for this article is retained by the author(s), with first publication rights granted to the journal.

This is an open-access article distributed under the terms and conditions of the Creative Commons Attribution license (http://creativecommons.org/licenses/by/3.0/). 